\title{
Creativity as Central to Critical Reasoning and the Facilitative Role of Moral Education: Utilizing Insights from Neuroscience
}

\author{
Terence Lovat ${ }^{1}$, Daniel Fleming ${ }^{2}$ \\ ${ }^{1}$ The University of Newcastle, Newcastle, Australia \\ ${ }^{2}$ The Broken Bay Institute, Sydney, Australia \\ Email: Terry.Lovat@newcastle.edu.au
}

Received 2 May 2015; accepted 23 June 2015; published 26 June 2015

Copyright (C) 2015 by authors and Scientific Research Publishing Inc.

This work is licensed under the Creative Commons Attribution International License (CC BY). http://creativecommons.org/licenses/by/4.0/

\section{(c) (i) Open Access}

\section{Abstract}

The article will review the literature of updated neuroscientific research in order to gain insights into the centrality to critical reasoning of creativity (understood as creative thinking, including the impulsion of imagination and wonder). Furthermore, it will explore literature that testifies to the credentials of moral education in facilitating the forms of creativity associated with the development of critical reasoning, as suggested by the insights of neuroscience. Finally, the article will review the literature related to earlier empirical evidence of the crucial role that moral education can play in facilitating creativity, imagination and wonder.

\section{Keywords}

\section{Creativity, Wonder, Imagination, Critical Reasoning, Moral Education, Neuroscience}

\section{Introduction}

The study design is a literature review aimed at eliciting evidence of new directions in education concerned with the central role of creativity, wonder and imagination in facilitating critical reasoning of the kind that impels educational achievement. Furthermore, it appraises literature that illustrates the potential of moral education to contribute to the development of creativity, wonder and imagination and to empirical evidence of this development. It begins by contextualizing current educational thinking that points to the creativity/critical reasoning link as evidenced in recent documentation in Australian education. 


\section{Linking Creativity and Critical Reasoning in Australian Educational Documentation}

As an instance of new and broader directions in holistic thought about learning, the Melbourne Declaration on Educational Goals for Young Australians (MCEETYA, 2008) identifies “creativity" among the essential skills for twenty-first century learners. An allied, supplementary document (ACARA, 2013), designed to outline the general capabilities needed to achieve the above goals, specifies the following:

Responding to the challenges of the twenty-first century-with its complex environmental, social and economic pressures - requires young people to be creative, innovative, enterprising and adaptable, with the motivation, confidence and skills to use critical and creative thinking purposefully (p. 66).

In underlining what it proposes to be an inherent link between creativity and critical reasoning, ACARA (2013) proffers:

Critical and creative thinking are integral to activities that require students to think broadly and deeply using skills, behaviours and dispositions such as reason, logic, resourcefulness, imagination and innovation in all learning areas at school and in their lives beyond school ... Creative thinking involves students in learning to generate and apply new ideas in specific contexts, seeing existing situations in a new way, identifying alternative explanations, and seeing or making new links that generate a positive outcome ... Dispositions such as inquisitiveness, reasonableness, intellectual flexibility, open- and fair-mindedness, a readiness to try new ways of doing things and consider alternatives, and persistence both promote and are enhanced by critical and creative thinking ... Critical and creative thinking can be encouraged simultaneously through activities that integrate reason, logic, imagination and innovation (pp. 66-67).

This Australian work is reflective of much attention in current educational scholarship to the links between creativity and critical reasoning. Such scholarship includes literature from a number of sources, as identified below. Higgins-D'Alessandro (2011) highlights the interconnections between rational, critical and imaginative thinking. Bryk (2012) underlines the need for educational policy that nurtures human creativity as a feature of the kind of reasoning required for effective learning. Newmann (2013), under the title "Muzzling Minds all over the Globe while Trumpeting Higher Order Skills", underlines the centrality of creativity and imagination to the most efficacious forms of higher order thinking (read "critical reasoning"). Scholarship that makes these connections has been strengthened by updated findings emanating from the neurosciences and the paper will now appraise an array of updated extant literature that strengthens the creativity/critical reasoning linkage.

\section{Neuroscience: Literary Evidence of the Centrality of Creativity}

The findings of neuroscience have become more certain with the advent of advanced technology capable of tracing and digitally representing activity within and among the fibres of the brain (Srinivasan, 2007; Jensen, 2008; Raichle, 2009; Friston et al., 2011; Meltzoff et al., 2009). These images confirm the nexus between activity more traditionally understood as cognition and the array of activities concerned with a range of other neural responses (Narvaez, 2010). Furthermore, these findings have been brought into a direct relationship with matters concerned with education, be it in its foundations, pedagogy or curriculum (Varma et al., 2008; Rosiek \& Beghetto, 2009; Immordino-Yang \& Faeth, 2010; Dommett et al., 2011; Hille, 2011; Immordino-Yang, 2011; Lovat et al., 2011; Schrag, 2011; Clement \& Lovat, 2012).

Within the array of neuroscientific data, there are particular elements that highlight the crucial nature of creativity for normal brain development, and most especially as a necessary facilitator of the type of critical reasoning ability most essential to effective learning. Doidge (2009) asserts that the findings of updated neuroscience have shifted fundamentally our conception of what the brain is and how it functions from one that sees it as 'hardwired' to one that is "plastic". By this, he means that we now know the cells and fibres in the brain to be so malleable as to be readily amenable to both external and internal influences. Experiences of joy, grief, love, hate, encouragement and discouragement will all impact on the way the brain functions and, over extended periods, how the brain grows and develops - or not. Similarly, Sajjadi (2008) argues that recent neuroscientific evidence renders the traditional notion of the "brain as machine" as quite inadequate if education is to optimize the potential for learning. Rather than seeing the brain as mechanistic and arborescent (or "tree-like"), we need to work on the conception that it is dynamic and rhizomatic (or "root-like"). Instead of the seemingly static tree, the brain is more 
like the ever-growing and expanding roots, influenced by the experiences to which the growing person is subjected, especially in the early years of development (Narvaez, 2013).

According to Narvaez $(2010,2013)$, the ramifications for educators rest with their capacity to impact on the brain's development through the kinds of content, curriculum and pedagogy they employ. Furthermore, the brain is so complex, with every element impacting on every other element, that learning must be a multivariate and enriching experience for students (Immordino-Yang \& Faeth, 2010). If learning challenges are all premised on the notion of the brain as "hardwired" and "mechanistic", being simply able to receive information, process and regurgitate it as required, then education has the potential to be a negative and even damaging process for students, especially for those not so well equipped to deal with simple reception, processing and regurgitation (Immordino-Yang \& Damasio, 2007). Not only can their self-esteem be damaged but, according to the assumptions of neuroplasticity, their brains can fail to grow in line with their potential (Doidge, 2009).

Narvaez $(2008,2010,2013,2014)$ takes the case further in the pivotal role she assigns to creativity as providing for the emotional stability that is essential to sound and critical reasoning. Herein, she employs updated neuroscientific evidence around the role of the pre-frontal cortex of the human brain, showing it to be its most evolved and distinctive feature. Especially in the context of a caring and nurturing environment, neural activity associated with imagination is the key to establishing the emotional regulation necessary to the forming of effective decision-making and problem-solving. In turn, the self-confidence that results from such decision-making and problem-solving becomes the basis of ongoing critical reasoning, and indeed of learning. A caring and nurturing environment is essential, but not sufficient, for this to occur. What is also needed is the guiding hand of efficacious pedagogy. Narvaez makes use of McGilchrist (2009) in identifying with some precision how the right and left hemispheres of the brain function, the left being more associated with rationality and the right with affectivity. Narvaez (2013) clearly, and perhaps surprisingly, associates creativity principally with left brain activity, with the neural capacity to abstract, reflect, self-reflect and problem solve. It is, in this sense, the key to unlocking the potential of critical reasoning to drive new learning. In her most recent work, Narvaez (2014) also links this aspect of creativity to a broader vision of flourishing for the human person, claiming that while modern, mostly Western, understandings of creativity have tended to concentrate on 'detached imagination focused on technical manipulation and innovation (p. 245). Narvaez claims that a more holistic understanding of human flourishing, which emphasises humankind's relatedness to the natural world, along with moral values such as generosity and compassion, is better positioned to allow for the full functioning of the human brain and, correlatively, its capacities for creativity.

We conclude this section of the literature review by referring to an array of prominent literature that captures the healthy scepticism that exists among educational researchers about the capacity and/or appropriateness of neuroscience being applied to education. Snook (2012) proposes that he is not opposed to scientific appraisal of education and that elements of neuroscience may well have something to offer but that we need to differentiate "good science" from fads and "neuromyths", among which he includes the notion of "left and right brain thinking". Weisberg et al. (2008) confirm the potential mischievousness of "neuromythology" through an empirical study that illustrated the "allure" of reference to neuroscience, even when irrelevant to the issue at hand, on the perceptions of study subjects, most especially non-expert subjects. Bruer $(1997,1998,2006)$ has gained a reputation as an arch-sceptic of neuroscience's relevance to education, arguing that the applications made are too often over-simplified links from biological evidence to the very different field of teaching and learning. He argues that the missing link in effective application is psychology and that, without its filter, many of the arguments proffered for neuroscience's implications for the practicalities of education are unfounded.

This authorship remains aware of the debate about and the contentiousness about the limitations of neuroscience for educational application (Clement \& Lovat, 2012) but, importantly also notes the many neuroscientists and educational psychologists, as illustrated above, who argue for and have achieved reputable empirical studies that seem to confirm the applicability of neuroscience's insights to education. This authorship makes no claim to scientific expertise but has proffered its own view that, regardless of the scientific argumentation one way or the other, the insights of neuroscience can be useful as metaphorical devices for analysing educational practices (Fleming \& Lovat, 2015 in press). Furthermore, it has written refereed work, including elements of its own empirical work (Fleming \& Lovat, 2014) that illustrates how such devices can be useful in education, especially in negotiating teaching and learning in challenging multicultural, multi-value contexts. In a word, we believe the authorship has demonstrated the creative potential of neuroscience insights being applied to educational thinking in a way that is particularly pertinent to the purpose of this article. 


\section{Creativity, Imagination and Wonder}

The article now expands on the literature review to incorporate a wider array of scholarship that has made use of neuroscience insights in proffering the crucial nature of imagination and wonder, as artefacts and extensions of creativity, in developing critical reasoning. While the three capacities connoted by creativity, imagination and wonder might be regarded as either insufficiently alike to be lumped together or so alike as to be unnecessarily separately named, we argue that the abovementioned updated neuroscientific evidence on which we rely shows that, on the one hand, they complement and complete each other in a particularly rich way but, on the other hand, that they each denote a facet of the evidence that justifies their being seen as synergistic but separate skills.

Jordan and Carlisle (2013) refer to creativity as "a conceptual ability to come up with new ideas that are surprising, yet intelligible" (p. 7). The earlier work of Dietrich (2004) utilized updated neuroscientific evidence in forging the links between creativity and intelligibility, showing that, especially when creativity is impelled by deliberate control (such as in a formal learning situation), it stimulates the pre-frontal cortex and, as identified above, it is the most developed and distinctively human part of the brain, the part on which critical reasoning relies most fully. Further research seems to confirm Dietrich's earlier work in this regard. Srinivasan (2007) employed EEG data in illustrating that creative tasks utilized the pre-frontal cortex, especially when related to "... effortful problem-solving tasks" (p. 109). In this sense, creativity can be seen to be a regular but vital component of intelligibility. Wegerif et al. (2010) went further in using artificial intelligence pattern matching techniques to show that creative activity could be coded and read by using more established critical thinking codes. Their work again underlines the synergy to be found in brain activity between creativity and critical reasoning.

In her 'Triune Ethics Theory' (TET), in essence a theory drawing on and directed to moral education, Narvaez $(2008,2013)$ also focuses on activity in the pre-frontal cortex necessary to the development of sound, critical reasoning, labouring the crucial part played by imaginative thinking in stimulating the left brain formation that is essential to the development of such reasoning. It could be argued that Narvaez might as well have used the language of "creativity", rather than "imagination", in this theory because the two words appear virtually synonymous. By utilizing imagination, however, Narvaez is able to explore a variant of neuroscientific research which delves even further into the workings of the brain and the similarities to be found between creativity and critical reasoning, while also making use of some of the more extended evidence of enriching by the former on the latter.

Imagination has been found to be a particularly important focus for neuroscientific research aimed at identifying the fine-tuned similarities and differences between creativity and intelligibility, as normally understood. Hassabis et al. (2007), for instance, used advanced brain scanning technology to trace similarities and differences in pre-frontal cortical activity between imagined fictitious experiences and episodic memory. In terms of the essential commonality of scene construction, there were 'remarkable similarities' in the effect on the prefrontal cortex. This finding in itself underlines an aspect of the synergy between creativity and intelligibility and offers clues to the educator about the vast and too often untapped potential for imaginative thinking to stimulate critical reasoning related to real-life experiences and dilemmas.

Hassabis et al. (2007) also point to the likelihood of other brain functions coming into play that discriminate between imagined fictitious experiences and episodic memory, a notion that adds even more value to imagination as an educational strategy, not least in an era that tends to privilege rationality and empiricism over creativity. Combining Hassabis et al. with Doidge's (2009) "rhizomatic" brain notion, it would seem that neuroscience is pointing to creativity as a distinctively powerful way in which the full functioning of the brain can be effected. Furthermore, we can see that through the use of the notion of imagination and imaginative thinking, this insight into creativity's potential can be strengthened. We will show below that, especially in the application of her thinking to moral education, Narvaez's use of imagination allows her to explore profound and unlikely dimensions of creativity, including potentially negative and quite destructive ones that would have stretched the normal meaning attached to the word and would go beyond the evidence, at least within the ambit of neuroscience.

Just as imagination adds value to the concept of creativity, as above, so the same can be said of "wonder". Bulkeley (2005), in The Wondering Brain, employs updated neuroscience to speak of the full range of emotions attached to those creative moments when something entirely new happens to one's intelligibility, powers of insight or what we refer to simply as critical reasoning. Bulkeley chooses to speak in this context of "wonder", which she defines as "... feeling excited by an encounter with something novel and unexpected, something that 
strikes a person as intensely real, true and/or beautiful" (p. 3). She points out that wonder has often been associated with the religious and moral traditions but that experiences of wonder have been "... crucial but unappreciated inspirations for ... scientific progress and technological innovations" (p. 3). Why is this so? Bulkeley asks, and then answers her own question in the following way:

To feel wonder is to experience a sudden decentering of the self. Facing something surprisingly new and unexpectedly powerful, one's ordinary sense of personal identity is dramatically altered, leading to new knowledge and understanding that ultimately recenter the self. The profound impact ... is evident in both the intense memorability of the experiences and the strong bodily sensations that often accompany them. People speak of being stunned, dazed, breath-taken, overwhelmed, consumed, astonished - all gesturing toward a mode of experience that exceeds ordinary language and thought and yet inspires a yearning to explore, understand and learn ... where the powerful emotional experience (of wonder) stimulates lively curiosity, knowledge-seeking behaviour and critical questioning" (p. 4).

Bulkeley (2005) makes much use of updated neuroscientific research around pre-frontal cortical activity in making her case about wonder as both an integral dimension of intelligibility as well as possessing potential to disrupt, disturb, de-activate and re-activate regular brain functions in order to stimulate the brain to expand its capacity for reasoning:

The large expanses of association cortex that distinguish the human brain are hyperactivated as radically new input must be processed, upsetting established neural systems and forcing the creation of new ones. In terms of the range and complexity of neural connections, I would propose as a testable hypothesis that wonder makes the brain grow... The capacity to experience wonder is itself a developmental achievement ... wonder as existential surprise becomes wonder as knowledge-seeking curiosity (pp. 198-199).

As above, we are conscious of the contentiousness that exists around the validity of applications from neuroscience to education and related matters, in the way Narvaez has done (see for example, Haidt, 2010). We are at the same time buoyed by the overall positive response from scholarship that her works (Narvaez et al., 2013; 2014) have received in formal academic reviews (Bielert \& Gallup, 2014), as well as previous evaluations of her approach (Lewis, 2010). It is similarly the case with Bulkeley's work which, in spite of the hearty debate about neuroscience's potential to inform about practical enterprises, has received very positive academic reviews (cf. Gortner, 2007). On the basis of such endorsement, we believe it is valid to continue to explore the insights of neuroscience in an endeavour to gain enhanced insight into the potential of creative, imaginative and wondrous thinking to impact on critical reasoning.

The case for creativity, imagination and wonder as complementary in the development of critical reasoning, yet beneficially separable in their emphases and orientations, rests on analyses such as those above. Furthermore, we see, especially in Narvaez and Bulkeley, important references to the moral dimension of the kind of creativity that has potential to facilitate critical reasoning. As such, we wish to explore literature that pertains to moral education as an area of learning with especially strong credentials in stimulating this kind of creativity.

\section{The Role of Moral Education in Cultivating Creativity}

As suggested above, Narvaez's concept of imagination as vital to the development of left brain activity leading to sound or critical reasoning is to be found in its most comprehensive form in her "Triune Ethics Theory" (Narvaez, 2008, 2013, 2014), a theory about human mindsets premised heavily on the impulsions we refer to as moral motivation and the desired intentions and directions of the enterprise we call moral education. Bulkeley's (2005) work on wonder is also set in the context of knowledge-gathering as an inherently moral enterprise when its goal is to truly extend the mind beyond the known to the new and surprising, for Bulkeley the only goal with capacity to stretch the powers of the brain. One gains a strong sense from these perspectives that the earlier philosophical positions of the likes of Dewey (1916) and Peters (1981), that all effective education is moral education, have been confirmed empirically in the updated neuroscientific evidence on which we are resting our case for the integral connections between creativity and critical reasoning.

The three mindsets to which Narvaez (2013) refers are safety, engagement and imagination, this latter associated most patently with the pre-frontal cortex of the brain. Despite its uniqueness, the operation of this dimension of the brain is not necessarily a positive thing; it can align itself with a security mindset and issue in 'vicious imagination'; this will most likely result if a person feels fear or insecurity, hence allowing imagination to impel 
negative thoughts and behaviours and, in turn, rigidifying brain activity. Bulkeley (2005) also notes the potential for fear resulting from the decentering that can accompany the experience of wonder. On the other hand, imagination can be allied with the engagement mindset and result in "communal imagination" (Narvaez, 2013, 2014), a confident and altruistic set of thoughts and behaviours that, among other things, enhances and enriches the growth and development of the brain.

There will be many factors in play that will determine which way imagination is directed, home life being one and the role of the teacher, school and school system being an important other dimension. Whichever social agency, the constant need is for a caring, trusting ambience. Bulkeley suggests of wonder that it requires “... a sufficient degree of safety and security ... so that the natural fear of being decentered does not smother the pleasurable creative response in seeking a new center" (p. 199). Narvaez (2014) pushes this point further to critique the whole ambience of contemporary Western society which, she argues, undermines communal imagination in its focus on threat and fear and she posits, instead, a return to the nurturing values of more primal cultures to better facilitate this aspect of human functioning (and in fact all of human flourishing). Both Narvaez and Bulkeley emphasize that it is the caring and trusting ambience, including the key people in any student's life that activates the kind of imagination and wonder that impels the emotional regulation that is essential to problemsolving, knowledge-seeking curiosity and critical reasoning. It is this kind of imagination and wonder that is associated with the capacity to engage in the deliberative and intuitive aspects of interaction and decision making. As such, education which places the value of the student at its centre - that is, a moral education-is best positioned to allow for the flourishing of creativity, imagination, and wonder.

Further to the important link between imagination, effective learning and moral motivation/ education, Narvaez (2013) proffers that communal imagination issues in a personality that "is able to move beyond immediate selfinterest, to conceptualize alternative social systems, think impartially about moral problems, counteract harmful instincts or behave altruistically" (p. 331). Communal imagination is closely aligned with the capacity for empathy, which is itself "a primary force behind moral behaviour" (p. 327). In turn, it is the imagination mindset that gives rise to the higher-order thinking capacities needed "for problem solving and deliberative learning" (p. 327), especially when it comes to critical moral reasoning. In this regard, Eslinger et al. (2009) note that such functions are among the most complex undertaken by the brain because it must draw on more sophisticated neural sources when it encounters moral situations that include novel or ambiguous dimensions. Hence, a case is premised for the crucial conjunction between creativity, critical reasoning and moral education. Furthermore, we believe evidence exists that confirms that this conjunction is beyond mere speculative theorizing. We point now to findings emanating from the moral education venture titled the Australian Values Education Program.

\section{Creativity and Critical Reasoning: Evidence from the Australian Values Education Program}

As above, research insights and findings from the neurosciences illustrate the importance of education being holistic in its focus. The learner is a whole person, impelled by cognitive, emotional and social drives, not as separable features but in holistic connection with each other. Narvaez (2013) identifies the vital connections between the caring and supportive learning environment that, together with stimulating imagination and creativity, nurture the emotional regulation essential for sound (critical) reasoning powers to develop. Hence, is seen the crucial importance of pedagogy that places students at the centre of the learning enterprise by establishing encouraging, trusting and caring ambiences of learning and, furthermore, engaging in curricula that stimulate creativity, imagination and wonder. Such environments are those that research has shown to be the most likely to produce sustained and effective improvements in learning (Newmann et al., 1996; Bryk \& Schneider, 2002; Rowe, 2004). There is now a vast store of evidence from research around moral education that the establishment of such ambiences of learning, together with explicit discourse about moral and values-oriented content in ways that draw on students' deeper learning and reflectivity, has power to transform their patterns of feelings, behaviour, resilience and academic diligence (cf. Hoffmann, 2000; Benninga et al., 2006; Lovat, 2010, 2011, 2013; Lovat \& Toomey, 2009; Lovat et al., 2009, 2010a, 2010b, 2010c, 2011a, 2011b; Berkowitz, 2011; Nucci \& Narvaez, 2008). The principal research drawn on here as supporting evidence is taken from a range of the core projects that ran under the umbrella of the Australian Values Education Program.

The Australian Values Education Program was a federally funded venture that began with a pilot study in 2003 (DEST, 2003), followed by the development of a National Framework for Values Education in 2005 (DEST, 2005) 
and a range of attached research and practice projects from 2005 to 2009, the most crucial of which were the two stages of the Values Education Good Practice Schools Project (VEGPSP) (DEST, 2006; DEEWR, 2008) and the Project to Test and Measure the Impact of Values Education on Student Effects and School Ambience (Lovat et al., 2009).

Findings from VEGPSP (DEST, 2006; DEEWR, 2008) illustrated that a sound values education program can be a powerful ally in the development of best practice pedagogy, with positive effects being demonstrated across the range of measures, including in terms of academic development. Project reports identified greater reflectivity and strengthened intellectual engagement among students and settling into work more readily and calmly as routine effects of the ambience created when moral and values-oriented considerations were driving the pedagogical approach. Reports also spoke of the enhanced academic diligence that resulted. In most cases, reports of strengthened intellectual understanding pointed not only to improved learning performance but equally to enhanced moral behaviour. This was seen in clear demonstrations of a stronger sense of student responsibility over local, national and international issues, improved relationships of care and trust, greater student awareness of the need to be tolerant of others, to accept responsibility for their own actions and their ability to communicate, with students' sense of belonging, connectedness, resilience and sense of self all being enhanced.

In the Project to Test and Measure the Impact of Values Education on Student Effects and School Ambience (Lovat et al., 2009), a mixed methods approach in the form of a sequential explanatory design (Creswell et al., 2003) was taken in order to test all of the claims arising from VEGPSP concerning student effects. Quantitative data were collected over two time-periods and analysed, with qualitative data being collected during the second phase and analysed separately to help explain and elaborate on the quantitative results. The qualitative data helped to refine and explain the statistical results by incorporating more detailed information from the perspectives of the research participants. Student, staff and parent pre and post surveys were administered in order to obtain quantitative and qualitative data about the effects of the program on student behaviour, student engagement, and classroom and school ambience. The results of the analysis of the teacher surveys revealed statistically significant improvements on these three measures.

The qualitative data also supported the above findings, with many comments from both students and teachers indicating that improved interactions between students had led to more harmonious and productive learning environments in which students were demonstrating greater kindness to each other and taking more care and pride in their work. The teachers observed that giving students more control over routine tasks added to their sense of competence and this appeared to lead to more independent learning and increased intrinsic motivation, impelled by strengthened critical reasoning powers. The teachers reported that students were putting greater effort into their work and "striving for quality", "striving to achieve their best" and even "striving for perfection":

Thus, there was substantial quantitative and qualitative evidence suggesting that there were observable and measurable improvements in students' academic diligence, including increased attentiveness, a greater capacity to work independently as well as more cooperatively, greater care and effort being invested in schoolwork and students assuming more responsibility for their own learning (Lovat et al., 2009: p. 6).

Consistent with the focus of this paper is the emphasis in the evidence on creativity, imagination and wonder playing a vital role in achieving students' demonstrable improvement in the powers of critical reasoning. In speaking about the enhanced opportunities to deepen reflection and so strengthen learning overall, a teacher wrote:

I now see the need, when I am discussing ideas with children, not just to draw on the children's experience, but rather to extend their understanding of reality. I have a responsibility to provide time and experiences for children to wonder. We need to wonder ourselves. This will help us to understand and improve relationships with others (DEST, 2006: p. 34).

In another cluster of schools in which disadvantage was a particular issue, the researcher wrote of the rights of children to respect, care and quality education and, in this context, of the importance of nurturing "... creativity, wonderment (so they could) learn to participate actively in planning for their (own) future" (DEST, 2006: p. 208).

Meanwhile, one of the researcher "friends" of a cluster of schools utilizing a "philosophy in the classroom" tool for their values education objectives, identified these objectives as "... a school ethos where students have the capacity to exercise judgement and responsibility in matters of morality, ethics and social justice, and the capacity to make rational and informed decisions about their lives" (DEST, 2006: p. 109). In speaking to the 
nature of the approach being taken to achieve the objective, the researcher had the following to say about the added value to critical reasoning of creativity and wonder:

Philosophy is often described as a thinking skills programme or a course in critical and creative thinking. While it is true that philosophy for children does improve students' critical and creative thinking skills, calling it a "thinking skills" programme does not do it justice. It does much more as well. Through implementing Philosophy in our respective school sites we aim to build on the students' own wonder and curiosity about ideas that are important to them. The subject matter of Philosophy is those common, central and contestable concepts that underpin both our experience of human life and all academic disciplines ... The central pedagogical tool and guiding ideal of Philosophy is the community of inquiry. In the community of inquiry, students work together to generate and then answer their own questions about the philosophical issues contained in purpose written materials or a wide range of other resources. Thinking in the community of inquiry is critical, creative, collaborative and caring (DEST, 2006: p. 109).

\section{Conclusion}

The article has selected an array of prominent literature in an attempt to capture some of the vital evidence emanating from neuroscientific research about the central role of creativity, imagination and wonder in stimulating critical reasoning. It furthermore identifies moral education as a particularly powerful form of learning in impelling the kind of creativity, imagination and wonder necessary to the development of critical reasoning. Finally, the article points to empirical evidence from the Australian Values Education Program that appears to confirm the case being made.

As evidenced within the article, the authors are conscious of the contentiousness surrounding neuroscience's capacity to inform the practicalities of education, especially in the direct way that proposes biological findings can be ramified to teaching and learning as though no filter is required. We take note of the cautions provided by the likes of Bruer and Snook in this regard. In spite of such important cautions, we nonetheless come down on the side of the weight of scholarship that proffers important insights being generated by neuroscience for educational considerations, including concerned with the role of creativity, wonder and imagination in facilitating the kind of critical reasoning that impels educational achievement. As suggested within the article, we believe that the weight of the literature tends to the view that such insights from neuroscience are at the very least useful as metaphors for re-thinking many of the traditional assumptions about how learning can best proceed.

\section{References}

ACARA (2013). General Capabilities in the Australian Curriculum. Canberra: Australian Curriculum Reporting and Assessment Authority. http://www.australiancurriculum.edu.au/GeneralCapabilities/General\%20capabilities.pdf

Benninga, J., Berkowitz, M., Kuehn, P., \& Smith, K. (2006). Character and Academics: What Good Schools Do. Phi Delta Kappan, 87, 448-452. http://dx.doi.org/10.1177/003172170608700610

Berkowitz, M. (2011). What Works in Values Education? International Journal of Educational Research, 50, 153-158. http://dx.doi.org/10.1016/j.ijer.2011.07.003

Bielert, C., \& Gallup, A. (2014). A Review of Darcia Narvaez, Kristin Valentino, Augustin Fuentes, James J. McKenna, and Peter Gray (Eds.), Ancestral Landscapes in Human Evolution: Culture, Childrearing and Social Wellbeing. New York: Oxford University Press. Evolutionary Psychology, 12, 1053-1055.

Bruer, J. (2006). Points of View: On the Implications of Neuroscience Research for Science Teaching and Learning: Are There Any? A Skeptical Theme and Variations: The Primacy of Psychology in the Science of Learning. CBE Life Sciences Education, 5, 104-110. http://dx.doi.org/10.1187/cbe.06-03-0153

Bruer, J. T. (1997). Education and the Brain: A Bridge Too Far. Educational Researcher, 26, 4-16. http://dx.doi.org/10.3102/0013189X026008004

Bruer, J. T. (1998). Let's Put Brain Science on the Back Burner. NASSP Bulletin, 82, 9-19. http://dx.doi.org/10.1177/019263659808259803

Bryk, A. (2012). Opening Remarks from the President at the US Professors of the Year Awards Program. Carnegie Foundation for the Advancement of Teaching. http://www.usprofessorsoftheyear.org/Winners/Previous Natl Winners/2012RemarksBryk.html

Bryk, A., \& Schneider, B. (2002). Trust in Schools: A Core Resource for Improvement. New York: Russell Sage Foundation. 
Bulkeley, K. (2005). The Wondering Brain: Thinking about Religion with and beyond Cognitive Neuroscience. New York: Routledge.

Clement, N. D., \& Lovat, T. (2012). Neuroscience and Education: Issues and Challenges for Curriculum. Curriculum Inquiry, 42, 534-557. http://dx.doi.org/10.1111/j.1467-873X.2012.00602.x

Creswell, J. W., Plano Clark, V. L., Gutmann, M., \& Hanson, W. (2003). Advanced Mixed Methods Research Designs. In A. Tashakkori, \& C. Teddlie (Eds.), Handbook of Mixed Methods in Social and Behavioural Research (pp. 209-240). Thousand Oaks, CA: Sage.

DEEWR, Department of Education, Employment and Workplace Relations (2008). At the Heart of What We Do: Values Education at the Centre of Schooling. Report of the Values Education Good Practice Schools Project-Stage 2. Melbourne: Curriculum Corporation. http://www.curriculum.edu.au/verve/ resources/VEGPSP-2 final 3.pdf

DEST, Department of Education Science and Training (2003). Values Education Study. Executive Summary Final Report, Melbourne: Curriculum Corporation. http://www.curriculum.edu.au/verve/ resources/VES Final Report14Nov.pdf

DEST, Department of Education Science and Training (2005). National Framework for Values Education in Australian Schools. Canberra: Australian Government Department of Education, Science and Training. http://www.curriculum.edu.au/verve/_resources/Framework_PDF_version_for the web.pdf

DEST, Department of Education Science and Training (2006). Implementing the National Framework for Values Education in Australian Schools. Report of the Values Education Good Practice Schools Project-Stage 1: Final Report, September 2006, Melbourne: Curriculum Corporation. http://www.curriculum.edu.au/verve/_resources/VEGPS1_FINAL_REPORT_081106.pdf

Dewey, J. (1916). Democracy and Education: An Introduction to the Philosophy of Education. New York: The Free Press.

Dietrich, A. (2004). The Cognitive Neuroscience of Creativity. Psychonomic Bulletin \& Review, 11, 1011-1026. http://dx.doi.org/10.3758/BF03196731

Doidge, N. (2009). The Brain That Changes Itself: Stories of Personal Triumph from the Frontiers of Brain Science. Melbourne: Scribe Publications.

Dommett, E. J., Devonshire, I. M., Plateua, C. R., Westwell, M. S., \& Greenfield, S. A. (2011). From Neuroscientific Theory to Classroom Practice. The Neuroscientist, 17, 282-288. http://dx.doi.org/10.1177/1073858409356111

Eslinger, P., Robinson-Long, M., Realmuto, J., Moll, J., de Oliveira-Souza, R., Tovar-Moll, F., Wang, J., \& Yang, Q. X. (2009). Developmental Frontal Lobe Imaging in Moral Judgment: Arthur Benton's Ensuring Influence 60 Years Later. Journal of Clinical and Experimental Neuropsychology, 31, 158-169. http://dx.doi.org/10.1080/13803390802298064

Fleming, D., \& Lovat, T. (2014). When Encounters between Religious Worldviews Are a Threat: Applying Triune Ethics Theory in a Religiously Diverse Landscape. Journal of Moral Education, 43, 377-393. http://dx.doi.org/10.1080/03057240.2014.945397

Fleming, D., \& Lovat, T. (2015). Learning as Leaving Home: Fear, Empathy and Hospitality in the Theology Classroom. Teaching Theology and Religion, 18, in Press.

Friston, K., Ashburner, J., Kiebel, S., Nichols, T., \& Penny, W. (2011). Statistical Parametric Mapping: The Analysis of Functional Brain Images. London: Academic Press.

Gortner, D. (2007). A Review of Kelly Bulkeley, The Wondering Brain: Thinking about Religion with and beyond Cognitive Neuroscience, New York: Routledge (2005). Anglican Theological Review, 89, 493-494.

Haidt, J. (2010). Moral Psychology Must Not Be Based on Faith and Hope: Commentary on Narvaez. Perspectives on Psychological Science, 5, 182-184. http://dx.doi.org/10.1177/1745691610362352

Hassabis, D., Kumaran, D., \& Maguire, E. (2007). Using Imagination to Understand the Neural Basis of Episodic Memory. Journal of Neuroscience, 27, 14365-14374. http://dx.doi.org/10.1523/JNEUROSCI.4549-07.2007

Higgins-D’Alessandro, A. (2011). The Structures of a Liberal Education. Ethos, 10, 4-9.

Hille, K. (2011). Bringing Research into Educational Practice: Lessons Learned. Mind, Brain, and Education, 5, 63-70. http://dx.doi.org/10.1111/j.1751-228X.2011.01111.x

Hoffman, M. L. (2000). Empathy and Moral Development: Implications for Caring and Justice. Cambridge: Cambridge University Press. http://dx.doi.org/10.1017/cbo9780511805851

Immordino-Yang, M. H. (2011). Implications of Affective and Social Neuroscience for Educational Theory. Educational Philosophy and Theory, 43, 98-103. http://dx.doi.org/10.1111/j.1469-5812.2010.00713.x

Immordino-Yang, M. H., \& Damasio, A. R. (2007). We Feel, Therefore We Learn: The Relevance of Affect and Social Neuroscience to Education. Mind, Brain, and Education, 1, 3-10. http://dx.doi.org/10.1111/j.1751-228X.2007.00004.x

Immordino-Yang, M., \& Faeth, M. (2010). Building Smart Students: A Neuroscience Perspective on the Role of Emotion and Skilled Intuition in Learning. In D. A. Sousa (Ed.), Mind, Brain, and Education: Neuroscience Implications for the 
Classroom (pp. 66-81). Bloomington, IN: Solution Tree.

Jensen, E. (2008). A Fresh Look at Brain-Based Education. Phi Delta Kappan, 89, 409-417. http://dx.doi.org/10.1177/003172170808900605

Lewis, P. (2010). The Emerging Comprehensive Psychology of Darcia Narvaez. Tradition \& Discovery, 37, 9-18. http://dx.doi.org/10.5840/traddisc2010/201137332

Lovat, T. (2010). Synergies and Balance between Values Education and Quality Teaching. Educational Philosophy and Theory, 42, 489-500. http://dx.doi.org/10.1111/j.1469-5812.2008.00469.x

Lovat, T. (2011). Values Education and Holistic Learning: Updated Research Perspectives. International Journal of Educational Research, 50, 148-152. http://dx.doi.org/10.1016/j.ijer.2011.07.009

Lovat, T. (2013). Values Education Programs. In J. Hattie, \& E. Anderman (Eds.), International Guide to Student Achievement (pp. 279-281). New York: Routledge.

Lovat, T., \& Toomey, R. (Eds.) (2009). Values Education and Quality Teaching: The Double Helix Effect. Dordrecht: Springer. http://dx.doi.org/10.1007/978-1-4020-9962-5

Lovat, T., Clement, N., Dally, K., \& Toomey, R. (2010b). Addressing Issues of Religious Difference through Values Education: An Islam Instance. Cambridge Journal of Education, 40, 213-227. http://dx.doi.org/10.1080/0305764X.2010.504599

Lovat, T., Clement, N., Dally, K., \& Toomey, R. (2010c). Values Education as Holistic Development for All Sectors: Researching for Effective Pedagogy. Oxford Review of Education, 36, 1-17. http://dx.doi.org/10.1080/03054985.2010.501141

Lovat, T., Clement, N., Dally, K., \& Toomey, R. (2011a). The Impact of Values Education on School Ambience and Academic Diligence. International Journal of Educational Research, 50, 166-171. http://dx.doi.org/10.1016/j.ijer.2011.07.008

Lovat, T., Dally, K., Clement, N., \& Toomey, R. (2011b). Values Pedagogy and Student Achievement: Contemporary Research Evidence. Dordrecht: Springer. http://dx.doi.org/10.1007/978-94-007-1563-9

Lovat, T., Toomey, R., \& Clement, N. (Eds.) (2010a). International Research Handbook on Values Education and Student Wellbeing. Dordrecht: Springer. http://dx.doi.org/10.1007/978-90-481-8675-4

Lovat, T., Toomey, R., Dally, K., \& Clement, N. (2009). Project to Test and Measure the Impact of Values Education on Student Effects and School Ambience. Report for the Australian Government Department of Education, Employment and Workplace Relations (DEEWR) by the University of Newcastle, Australia, Canberra: DEEWR.

http://www.curriculum.edu.au/verve/ resources/Project to Test and Measure the Impact of Values Education.pdf

MCEETYA (2008). Declaration on Educational Goals for Young Australians. Melbourne: Ministerial Council on Education, Employment, Training \& Youth Affairs.

www.curriculum.edu.au/verve/_resources/National_Declaration_on the Educational_Goals_for_Young_Australians.pdf

McGilchrist, I. (2009). The Master and His Emissary: The Divided Brain and the Making of the Western World. New Haven, CT: Yale University Press.

Meltzoff, A., Kuhl, P., Movellan, J., \& Sejnowski, T. (2009). Foundations for a New Science of Learning. Science, 325, 284288. http://dx.doi.org/10.1126/science.1175626

Narvaez, D. (2008). Triune Ethics: The Neurobiological Roots of Our Multiple Moralities. New Ideas in Psychology, 26, 95119. http://dx.doi.org/10.1016/j.newideapsych.2007.07.008

Narvaez, D. (2010). The Emotional Foundations of High Moral Intelligence. New Directions for Child and Adolescent Development, 2010, 77-94. http://dx.doi.org/10.1002/cd.276

Narvaez, D. (2013). Neurobiology and Moral Mindset. In K. Heinrichs, F. Oser, \& T. Lovat (Eds.), Handbook of Moral Motivation: Theories, Models, Applications (pp. 323-342). Rotterdam: Sense Publishers.

http://dx.doi.org/10.1007/978-94-6209-275-4_19

Narvaez, D. (2014). Neurobiology and the Development of Human Morality: Evolution, Culture, and Wisdom. New York: W. W. Norton \& Company.

Narvaez, D., Panksepp, J., Schore, A. N., \& Gleason, T. R. (2013). Evolution, Early Experience and Human Development: From Research to Practice and Policy. Oxford: Oxford University Press.

Narvaez, D., Valentino, K., Fuentes, A., McKenna, J., \& Gray, P. (Eds.) (2014). Ancestral Landscapes in Human Evolution: Culture, Childrearing and Social Wellbeing. New York: Oxford University Press. http://dx.doi.org/10.1093/acprof:oso/9780199964253.001.0001

Newmann, F. (2013). Muzzling Minds All over the Globe While Trumpeting Higher Order Skills. http://www.invisibleserfscollar.com/tag/fred-newmann/

Newmann, F. M., \& Associates (1996). Authentic Achievement: Restructuring Schools for Intellectual Quality. San Francisco, CA: Jossey-Bass Publishers. 
Nucci, L., \& Narvaez, D. (Eds.) (2008). Handbook of Moral and Character Education. New York: Routledge.

Peters, R. S. (1981). Moral Development and Moral Education. London: George Allen \& Unwin.

Raichle, M. E. (2009). A Brief History of Human Brain Mapping. Trends in Neurosciences, 32, 118-126. http://dx.doi.org/10.1016/j.tins.2008.11.001

Rosiek, J., \& Beghetto, R. (2009). Emotional Scaffolding: The Emotional and Imaginative Dimensions of Teaching and Learning. In P. Schutz, \& M. Zembylas (Eds.), Advances in Teacher Emotion Research: The Impact on Teachers' Lives (pp. 175-194). Dordrecht: Springer. http://dx.doi.org/10.1007/978-1-4419-0564-2 9

Rowe, K. (2004). In Good Hands? The Importance of Teacher Quality. Educare News, 149, 4-14.

Sajjadi, S. M. (2008). Religious Education and Information Technology: Challenges and Problems. Teaching Theology and Religion, 11, 185-190. http://dx.doi.org/10.1111/j.1467-9647.2008.00469.x

Schrag, F. (2011). Does Neuroscience Matter for Education? Educational Theory, 61, 221-237. http://dx.doi.org/10.1111/j.1741-5446.2011.00401.x

Snook, I. (2012). Educational Neuroscience: A Plea for Radical Scepticism. Educational Philosophy and Theory, 44, 445449. http://dx.doi.org/10.1111/j.1469-5812.2011.00831.x

Srinivasan, N. (2007). Cognitive Neuroscience of Creativity: EEG Based Approaches. Science Direct, 42, 109-116. http://dx.doi.org/10.1016/j.ymeth.2006.12.008

Varma, S., McCandliss, B., \& Schwartz, D. (2008). Scientific and Pragmatic Challenges for Bridging Education and Neuroscience. Educational Researcher, 37, 140-152. http://dx.doi.org/10.3102/0013189X08317687

Wegerif, R., McLaren, B. M., Chamrada, M., Scheuer, O., Mansour, N., Mikšátko, J., \& Williams, M. (2010). Exploring Creative Thinking in Graphically Mediated Synchronous Dialogues. Computers \& Education, 54, 613-621. http://dx.doi.org/10.1016/j.compedu.2009.10.015

Weisberg, D., Keil, F., Goodstein, G., Rawson, E., \& Gray, J. (2008). The Seductive Allure of Neuroscience Explanations. Journal of Cognitive Neuroscience, 20, 470-477. http://dx.doi.org/10.1162/jocn.2008.20040 